\title{
Seedling development of nodulating and non-nodulating native legumes in soils from Brazilian Caatinga biome
}

\author{
Kelly Alexsandra Souza Menezes ${ }^{1}$, Gersika Fakirra de Oliveira Nunes ${ }^{1}$, Aline Araujo Sampaio', \\ Saulo de Tarso Aidar ${ }^{2}$, Lindete Míria Vieira Martins ${ }^{1}$, and Paulo Ivan Fernandes-Júniorº
}

\begin{abstract}
This study aimed to evaluate the initial development of the nodulating legumes jurema-rosa (Mimosa verrucosa Benth.) and angico [Anadenanthera colubrina (Vell.) Brenan] and the non-nodulating legumes umburana-de-cheiro [Amburana cearensis (Allemao) A.C. Smith] and caatingueira-verdadeira [Poincianella pyramidalis (Tul.) L.P. Queiroz]. Plants were grown in pots containing soil samples from six areas in Brazilian Caatinga biome region. Differences at the nodulation in plant roots were observed among the soils studied, pointing out a Vertisol covered by an introduced legume. The leaf gas exchange evaluations also showed differences among the plants grown in the different soils used as substrate mainly to angico and caatingueira-verdadeira.
\end{abstract}

Keywords: tree legume; nodulation; photosynthesis; semi-arid

\section{Introduction}

The Caatinga biome occurs exclusively in Brazil and covers the major part of the Brazilian Northeastern and at the north of Minas Gerais state. This biome shows, as main features, the low annual precipitation rates (below

Received: 14 November 2014

Accepted revised version: 22 December 2014

Published online: 03 April 2015

(C) Menezes et al. (2015)

Publisher: Horizon e-Publishing Group

CITATION

K. A. S. Menezes, G. F. O. Nunes, A. A. Sampaio, S. T. Aidar, L. M. V. Martins, P. I. Fernandes-Júnior. 2015. Seedling development of nodulating and non-nodulating native legumes in soils from Brazilian Caatinga biome. Plant Science Today 2(2): 56-59. doi: 10.14719/pst.2015.2.2.97

\section{AUTHORS' AFFILIATIONS}

1 Universidade do Estado da Bahia, Departamento de Tecnologias e Ciências Sociais, Juazeiro, Bahia state, Brazil.

2 Embrapa Semiárido, Petrolina, Pernambuco state, Brazil.

CORRESPONDENCE

\. Paulo Ivan Fernandes-Júnior - Email: paulo.ivan@embrapa.br
$800 \mathrm{~mm}$ ), high diurnal temperatures and high incidence of solar radiation. Because of its characteristics, Caatinga harbors highly adapted plant species. Due to, at least, two hundred years of unplanned anthropic exploration of the region, there are nowadays several areas with advanced desertification stages what conduce to several social, economic and environmental losses (Sá and Angelotti, 2009).

To carry out the land reclamation of these areas reintroduction of the native plant species by the introduction of healthy seedlings in the field is desirable. For the native species it is necessary to conduct studies to evaluate plant development and biological interactions to select the most suitable species to field re-introduction. Among all native plants from Caatinga, legume (Fabaceae) is the most abundant family with 86 genus and more than 320 species (Queiroz, 2009). Several of these species is able to associate symbiotically with a wide range of indigenous nitrogen fixing bacteria (collectively called of rhizobia) (Reis Júnior et al., 2010; Teixera et al., 2010; Freitas et al., 2014; Freitas et al., 2015) and these associations can be exploited to increase success of the seedlings establishment in the field.

In the last few years, studies had pointed out to the presence of efficient (Freitas et al., 2010) and diverse (Freitas et al., 2014) indigenous rhizobial communities that help the plant establishment and the seedlings development at the field. In spite of its importance to select more adapted plant species, evaluations regarding the plant physiology in nodulated and non-nodulated legumes from Caatinga is scarce. The results obtained from these evaluations should conduce to a better understanding of plant adaptations and its interaction with rhizobial symbionts. It this context, the aim of this study was to evaluate the initial development of legume seedlings cultivated in pots containing different soil samples from Caatinga Biome.

\section{Materials and Methods}

Samples of the A horizon (0-0.2 m depth) of six soils were sampled at Juazeiro (Bahia state) and Araripina 
(Pernambuco state) municipalities. For each sample, at least six sub samples collected at the site in the field. The sampling sites presented different characteristics, briefly described below. Sample 1 (CX1): Haplustult, Juazeiro, BA (40²5'06"W; 9³5'38”S), a sandy loam soil at Carnaíba do Sertão district. Very degraded area with sparse tree vegetation and nude soil; Sample 2 (T1): Luvisol, Juazeiro, BA (40³9'02”W; 9³2'45”S), a sandy loam soil in a preserved area at UNEB (Universidade do Estado da Bahia) Forest Farm. Presence of several tree species surrounded by the Salitre Irrigated perimeter. Abundance of native tree species.

The soil samples were homogenized, sieved and used to fill plastic pots with capacity of $1 \mathrm{~L}$. Each soil sample was evaluated according to its fertility properties (data not shown). The nodulating species evaluated were juremarosa (Mimosa verrucosa Benth.) and angico [Anadenanthera colubrina (Vell.) Brenan]. The nonnodulating species amburana-de-cheiro [Amburana cearensis (Allemao) A.C. Smith] and caatingueira-

Table 1: Development, gas exchanges and nodulation of legume seedlings in six soils from Caatinga.

\begin{tabular}{|c|c|c|c|c|c|c|c|c|c|c|c|c|}
\hline Soil & $\begin{array}{l}\text { SDW* } \\
\text { g plant }^{-1}\end{array}$ & $\begin{array}{c}\text { Nod } \\
\text { nodule } \\
\text { plant }^{-1}\end{array}$ & $\begin{array}{c}\boldsymbol{A} \\
\mathrm{umol} \mathrm{CO} \mathrm{CO}_{2} \\
\mathrm{~m}^{-2} \mathrm{~s}^{-1}\end{array}$ & $\begin{array}{c}g_{\mathrm{s}} \\
\mathrm{mol} \mathrm{H}_{2} \mathrm{C}\end{array}$ & $m^{-2} s^{-1}$ & $\left(\mathrm{~A} \mathrm{E}^{-1}\right)$ & Soil & g plant $^{-1}$ & $\begin{array}{c}\boldsymbol{A} \\
\underset{\mathrm{m}^{-2} \mathrm{~s}^{-1}}{\mathrm{umol} \mathrm{CO}_{2}}\end{array}$ & $\begin{array}{c}\boldsymbol{g}_{\mathrm{s}} \\
\mathrm{mol} \mathrm{H}_{2} \mathrm{O}\end{array}$ & $\mathrm{m}^{-2} \mathrm{~s}^{-1}$ & $\left(\mathrm{~A} \mathrm{E}^{-1}\right)$ \\
\hline \multicolumn{7}{|c|}{ Jurema-rosa (Mimosa verrucosa) } & \multicolumn{6}{|c|}{ Caatingueira-verdadeira (Poincianella pyramidalis) } \\
\hline CX1 & $0.47 \mathrm{~b}$ & $9 \mathrm{a}$ & $8.21 \mathrm{a}$ & $0.07 \mathrm{a}$ & $2.79 \mathrm{~b}$ & 2.94 & CX1 & $0.88 \mathrm{a}$ & $5.03 \mathrm{a}$ & $0.057 \mathrm{a}$ & $2.27 \mathrm{a}$ & 2.21 \\
\hline T1 & $0.17 \mathrm{c}$ & $0 \mathrm{~b}$ & $7.30 \mathrm{a}$ & $0.11 \mathrm{a}$ & $3.79 \mathrm{~b}$ & 1.92 & T1 & $0.12 b$ & $6.94 \mathrm{a}$ & $0.068 \mathrm{a}$ & $2.48 \mathrm{a}$ & 2.79 \\
\hline LA1 & $0.35 \mathrm{~b}$ & $0 \mathrm{~b}$ & $12.70 \mathrm{a}$ & $0.16 \mathrm{a}$ & $5.49 \mathrm{a}$ & 2.31 & LA1 & $0.96 \mathrm{a}$ & $7.05 \mathrm{a}$ & $0.068 \mathrm{a}$ & $2.23 \mathrm{a}$ & 3.16 \\
\hline $\mathbf{V 1}$ & $0.39 \mathrm{~b}$ & $4 \mathrm{a}$ & $10.08 \mathrm{a}$ & $0.10 \mathrm{a}$ & $3.34 \mathrm{~b}$ & 3.01 & V1 & $1.44 \mathrm{a}$ & $6.86 \mathrm{a}$ & $0.063 \mathrm{a}$ & $2.39 \mathrm{a}$ & 2.87 \\
\hline V2 & $0.93 \mathrm{a}$ & $10 \mathrm{a}$ & $8.79 \mathrm{a}$ & $0.10 \mathrm{a}$ & $3.84 \mathrm{~b}$ & 2.31 & $\mathbf{V} 2$ & $1.28 \mathrm{a}$ & $3.66 \mathrm{~b}$ & $0.030 \mathrm{a}$ & $1.32 \mathrm{~b}$ & 2.77 \\
\hline PVA1 & $0.57 \mathrm{~b}$ & $0 \mathrm{~b}$ & $9.39 \mathrm{a}$ & $0.16 \mathrm{a}$ & $6.11 \mathrm{a}$ & 1.53 & PVA1 & $1.31 \mathrm{a}$ & $3.28 \mathrm{~b}$ & $0.057 \mathrm{a}$ & $0.81 \mathrm{~b}$ & 4.05 \\
\hline \multicolumn{7}{|c|}{ Angico (Anadenathera colubrina) } & \multicolumn{6}{|c|}{ Umburana-de-cheiro (Amburana cearensis) } \\
\hline CX1 & $0.32 \mathrm{~b}$ & $1 \mathrm{~b}$ & $9.23 \mathrm{~b}$ & $0.08 \mathrm{~b}$ & $2.69 \mathrm{~b}$ & 3.43 & CX1 & $1.32 \mathrm{a}$ & $7.40 \mathrm{a}$ & $0.060 \mathrm{a}$ & $2.40 \mathrm{a}$ & 3.08 \\
\hline T1 & $0.15 \mathrm{c}$ & $0 \mathrm{~b}$ & $11.05 \mathrm{~b}$ & $0.12 b$ & $4.40 \mathrm{a}$ & 2.51 & T1 & $1.99 \mathrm{a}$ & $6.77 \mathrm{a}$ & $0.057 \mathrm{a}$ & $2.54 \mathrm{a}$ & 2.66 \\
\hline LA1 & $0.36 \mathrm{~b}$ & $0 \mathrm{~b}$ & $9.17 \mathrm{~b}$ & $0.08 \mathrm{~b}$ & $2.85 \mathrm{~b}$ & 3.21 & LA1 & $1.33 \mathrm{a}$ & $6.89 a$ & $0.050 \mathrm{a}$ & $2.15 \mathrm{a}$ & 3.2 \\
\hline V1 & $1.17 \mathrm{a}$ & $15 \mathrm{a}$ & $7.33 \mathrm{~b}$ & $0.06 \mathrm{~b}$ & $2.17 \mathrm{~b}$ & 3.37 & V1 & $1.54 \mathrm{a}$ & $5.31 \mathrm{a}$ & $0.030 \mathrm{a}$ & $1.24 \mathrm{a}$ & 4.28 \\
\hline V2 & $0.55 \mathrm{~b}$ & $0 \mathrm{~b}$ & $14.02 \mathrm{a}$ & $0.17 \mathrm{a}$ & $6.15 \mathrm{a}$ & 2.28 & V2 & $1.35 \mathrm{a}$ & $7.00 \mathrm{a}$ & $0.060 \mathrm{a}$ & $2.56 \mathrm{a}$ & 2.73 \\
\hline PVA1 & $0.30 \mathrm{~b}$ & $0 \mathrm{~b}$ & $14.98 \mathrm{a}$ & $0.13 \mathrm{~b}$ & $4.85 \mathrm{a}$ & 3.08 & PVA1 & $1.55 \mathrm{a}$ & $4.79 \mathrm{a}$ & $0.030 \mathrm{a}$ & $1.44 \mathrm{a}$ & 3.26 \\
\hline
\end{tabular}

*SDW=shoot dry weigh; Nod=nodulation; $A=$ net photosynthesis; $g_{\mathrm{s}}=$ stomatal conductance; $E=$ transpiration; WUE=water use efficiency

Values are the average of three replications.

Means followed by the same letters in the column at in the same specie do not differ by the Scott-Knott means test at $10 \%$ of probability.

including a high diversity of legumes; Sample 3 (LA1): Oxisol, Araripina, PE (40³6'00”W; $\left.7^{\circ} 29^{\prime} 00^{\prime \prime} \mathrm{S}\right)$, a sandy loam soil at the preserved area of IPA (Instituto Agronômico de Pernambuco) experimental station with a dense tree and shrubs vegetation; Sample 4 (V1): Vertisol, Juazeiro, BA, a clay soil $\left(40^{\circ} 25^{\prime} 27^{\prime \prime} \mathrm{W} ; 9^{\circ} 26^{\prime} 40^{\prime \prime} \mathrm{S}\right)$ located at the IRPAA (Instituto Regional da Pequena Propriedade Apropriada). Anthropized area where there is a dense Prosopis juliflora plantation; Sample 5 (V2): Vertisol, Juazeiro, BA (40²1'32”W; 943'46"S), clay soil at Juremal district. Preserved area at CODEVASF (Companhia do Desenvolvimento do Vale do São Francisco) reserve with a high diversity of cactus, trees and shrubs; Sample 6 (PVA1): Typic Haplustult, Juazeiro, BA $\left(40^{\circ} 36^{\prime} 43^{\prime \prime} \mathrm{W}\right.$; $9^{\circ} 31^{\prime} 46^{\prime \prime}$ ), sandy soil at the preserved area of CODEVASF verdadeira [Poincianella pyramidalis (Tul.) L.P. Queiroz] were also evaluated. Before sowing, the seeds were superficially disinfected with immersion in $96^{\circ} \mathrm{GL}$ ethanol for $30 \mathrm{~s}, 33 \%(\mathrm{v} / \mathrm{v})$ hydrogen peroxide for 3 minutes followed by ten washes in distilled and autoclaved water (Vincent, 1970). Six seeds were sowed per pot and, 20 days after the emergence (DAE), only two plants were allowed to remain. At 110 DAE the evaluation of the leaf gas exchanges were conducted. These evaluations were carried out with an infra-red gas analyzer (IRGA, Licor6400, Lincoln, Nebraska, USA) between 9:00 and 11:00 am. The measurements were performed in the second youngest leaves fully expanded (one leaf per plant) under clean sky. The photosynthetically active radiation applied was $1200 \mu \mathrm{mol}$ photons $\mathrm{m}^{-2} \mathrm{~S}^{-2}$ for the estimation of net 
photosynthesis $\left(A, \mu\right.$ mol $\left.\quad \mathrm{CO}_{2} \quad \mathrm{~m}^{-2} \mathrm{~s}^{-1}\right)$, the somatic conductance $\left(g_{\mathrm{s}}, \mathrm{mol} \mathrm{H}_{2} \mathrm{O} \mathrm{m}^{-2} \mathrm{~s}^{-1}\right)$ and the transpiration $(E$, mol $\mathrm{H}_{2} \mathrm{O} \mathrm{m}^{-2} \mathrm{~s}^{-1}$ ) (Caemmerer and Farquhar, 1981). In the next day (at the $111 \mathrm{DAE}$ ) the plants were harvested, the shoots were separated from the roots and dried at an air circulation chamber at $65^{\circ} \mathrm{C}$ for four days and weighted. For jurema-rosa and angico species, the number of nodules per plant was also determined. The experiment was conducted from March to June, 2011. The experimental design adopted was randomized blocks with three replications. The data were evaluated using the software Sisvar (UFLA).

\section{Results and Discussion}

The nodulation of angico and jurema-rosa at the six soils studied showed that angico was able to nodulate at the CX1 and V1, while the jurema-rosa showed nodules at the soils CX1, V1 and V2 (Table 1). At the V1 soil, angico nodulated abundantly and jurema-rosa also presented nodules. This area was covered by a dense plantation of algaroba that is a nodulating Mimosoid legume. As well as algaroba, the angico and jurema-rosa also belong to Mimosoid sub-family and the presence of a nodulating Mimosoid may select a community of nodulating bacteria able to form nodules in related species, for example those $\beta$-rhizobia bacteria belonging to Burkholderia genus (Reis Júnior et al., 2010). The absence of nodulation of these species at the other soils indicates that the rhizobial community is not effective for the species studied. At the plants with the highest nodulation rates, higher values to the shoot dry mass were also observed, indicating a well nitrogen nutrition and, possibly, the growth promoting activity of rhizobia (Döbereiner, 1966).

Direct correlation between nodulation status and the photosynthetic rates was not observed. Surprisingly, the high photosynthesis rates found to angico were achieved at the V2 and PVA1 where this species failed to nodulate. On the other hand, the non-nodulating caatingueiraverdadeira showed the lower photosynthesis levels at V2 and PVA1. The jurema-rosa and umburana-de-cheiro did not present differences in photosynthesis among the soils. These results indicated that the net photosynthesis of these four legumes is influenced by the soil but there is the influence of other intrinsic factors of the species. As well as the lower net photosynthesis, caatingueiraverdadeira also showed lower transpiration rate at the V2 and PVA1. The same tendency was observed in angico plants which exhibited higher transpiration levels in the same soils where the plants showed the higher net photosynthesis (V2 and PVA1). Although we did not observe statistical differences among the stomatal conductance at caatingueira seedlings at the different soils and at the angico plants cultivated at the V2 (compared with the other soils within angico), the absolute values (higher to angico and lower to caatingueira), supported by net photosynthesis and transpiration, suggests that, in these plants, the stomatic opening allow a high concentration of intercellular $\mathrm{CO}_{2}$ maximizing the carboxilative role of Rubisco.

Plants species native from Caatinga are able to develop differently when cultivated in different substrates (Pimental and Guerra, 2011) is in agreement with the results of the present study. Evaluating the grain legumes (e.g. soybean), the nodulation is closely related to photosynthetic behavior (Kaschuk et al., 2012). However, source/sink relation of $\mathrm{C}$ and $\mathrm{N}$ is not well understood in Caatinga species. In addition, the evaluations concerning the physiology and development of the native legumes in different soils are rare and, to our knowledge, this is the first study evaluating the development and gas exchange parameters in jurema-rosa, angico, caatingueira and umburana-de-cheiro in pots containing different soil samples from Brazilian Caatinga.

\section{Competing interests}

The authors declare that they have no competing interests.

\section{Acknowledgments}

To Capes for the granted scholarships. To UNEB and to Embrapa Semiárido for their financial assistance and infrastructure.

\section{References}

Caemmerer, S., and G.D. Farquhar. 1981. Some relationships between the biochemistry of photosynthesis and the gas exchange of leaves. Planta 153: 376-387. doi: 10.1007/BF00384257

Dobereiner, J. 1966. Evaluation of nitrogen fixation in legumes by the regression of total plant nitrogen with nodule weight. Nature 210: 850-852. doi: 10.1038/210850a0

Freitas, A.D.S., E.V.S.B. Sampaio, A.P.S. Ramos, M.R.V. Barbosa, R.P. Lyra, E.L. Araújo. 2015. Nitrogen isotopic patterns in tropical forests along a rainfall gradient in Northeast Brazil. Plant and Soil, doi:10.1007/s11104-015-2417-5

Freitas, A.D.S., E.V.S.B. Sampaio, C.E.R.S Santos, and A.F. Silva. 2010. Biological nitrogen fixation in tree legumes of the brazilian semi-arid Caatinga. Journal of Arid Environments 74: 344-349. doi:10.1016/j.jaridenv.2009.09.018

Freitas, A.D.S., W.L. Borges, M.M.M. Andrade, E.V.S.B. Sampaio, C.E.R.S. Santos, S.R. Passos, G.R. Xavier, B.M. Mulato, and M.C.C.P. Lyra. 2014. Characteristics of nodule bacteria from Mimosa spp grown in soils of the Brazilian semiarid region. African Journal of Microbiology Research 8: 788-796. doi: 10.5897/AJMR2013.6518

Kaschuk, G., X. Yin, M. Hungria, P.A. Leffelaar, K.E. Guiller, and T.W. Kuyper. 2012. Photosynthetic adaptation of soybean due to varying effectiveness of $\mathrm{N}_{2}$ fixation by two distinct Bradyrhizobium japonicum strains. Environmental and Experimental Botany 76: 1-6. doi: 10.1016/j.envexpbot.2011.10.002

Pimentel, J.V.F. and H.O.C. Guerra. 2011. Irrigação, matéria 
orgânica e cobertura morta na produção de mudas de cumaru (Amburana cearensis). Revista Brasileira de Engenharia Agrícola e Ambiental, 15, 896-902. doi: 10.1590/S1415-43662011000900004

Queiroz, L.P. 2009. Leguminosas da Caatinga. Feira de Santana, UEFS. 443 pp.

Reis Júnior, F.B., M.F. Simon, E. Gross, R.M. Boddey, G.N. Elliott, N. Neto, M.F. Loureiro, L.P. Queiroz, M.R. Scotti, W.M. Chen, A. Norén, M.C. Rubio, S.M. Faria, C. Bontemps, S.R. Goi, J.P.W. Young, J.I. Sprent, and E.K. James. 2010. Nodulation and nitrogen fixation by Mimosa spp. in the Cerrado and Caatinga biomes of Brazil. New Phytologist, 186: 934-946. doi: 10.1111/j.1469-8137.2010.03267.x

Sá, I.B. and F. Angelotti. 2009. Degradação ambiental e desertificação no semi-árido brasileiro. In. Angelotti, F., I.B. Sá, E.A. Menezes, and G.Q. Pellegrino. Mudanças climáticas $e$ desertificação no semi-árido brasileiro. Petrolina: Embrapa Semiárdo, p. 59-88

Teixeira, F.C.P., W.L. Borges, G.R. Xavier, and N.G. Rumjanek. 2010. Characterization of indigenous rhizobia from Caatinga. Brazilian Journal of Microbiology, 41: 201-208. doi: 10.1590/S1517-83822010000100029

Vincent, J.M. 1970. A manual for the practical study of root nodule bacteria. Oxford, Blackwell Scientific. $164 \mathrm{pp}$ 